\title{
Possible Correlation Between Some Chronic Pesticides Exposure and Disturbance in Thyroid Hormones Levels and Some Biochemical Markers.
}

\author{
Mostafa A. Mohamed ${ }^{1}$ and Khaled M. Taha ${ }^{2}$
}

\begin{tabular}{|c|c|}
\hline & ABSTRACT \\
\hline $\begin{array}{l}\text { KEYWORDS } \\
\text { Pesticides, } \\
\text { Thyroid hormones, } \\
\text { HPLC, } \\
\text { Biochemical analysis. }\end{array}$ & $\begin{array}{l}\text { Pesticides are often used indiscriminately in large amounts causing } \\
\text { environmental pollution. Pesticides cause adverse effects on different body systems, } \\
\text { including hematological and endocrine systems. The ability of pesticides to disturb } \\
\text { thyroid function remains unclear. So, the present work studied the possible } \\
\text { correlation between chronic some pesticides exposure, used at least within the past } 12 \\
\text { months, such as phosphoro di thionate (PDT) and dichloro-diphenyl trichloroethane } \\
\text { (DDT) and disturbance in both thyroid hormones levels and some biochemical } \\
\text { markers. The study was conducted from the } 1^{\text {st }} \text { of December } 2016 \text { to } 1^{\text {st }} \text { of July } 2017 \text {. } \\
\text { It involved } 100 \text { cases who were recruited from general internal medicine of Al-Azhar } \\
\text { and Mansoura University Hospitals, in addition to } 50 \text { subjects as a control group } \\
\text { from medical students. After free informed consent, } 10 \mathrm{~mL} \text { of blood were separated } \\
\text { and the serum was divided into three aliquots, one of which for residues extraction of } \\
\text { (PDT) and (DDT) by using high performance liquid chromatography (HPLC) and } \\
\text { two of which were stored at -8 C for routine laboratory investigation including } \\
\text { thyroid hormones levels. Cases and controls were subjected to a standardized } \\
\text { questionnaire. Then clinical examination to all groups was done stressing on } \\
\text { manifestation of thyroid disease. In general a disturbance in thyroid hormones levels } \\
\text { (hypothyroidism) in the present study, revealed a strong correlation between it and } \\
\text { working or exposures to PDT (Malathion) as it is positive in (46.0\%) and (DDT) as it } \\
\text { is positive in (55.0\%), especially among agriculture working in rural area. There is a } \\
\text { significant difference between cases and control groups as regard; serum creatinine, } \\
\text { serum cholesterol, high-density lipoproteins, low-density lipoproteins and thyroid } \\
\text { hormones. There is also significant positive correlation between pesticide exposures } \\
\text { and TSH level. It is recommended that any patients with suspect a manifestation of } \\
\text { hypothyroidism must be screened for pesticides especially in rural areas dealing with } \\
\text { them. }\end{array}$ \\
\hline
\end{tabular}

\section{Introduction}

Pesticides are chemical or biological substances used to kill or repel targeted organisms (Gilden et al., 2010). During the past 50 years, pesticides have had an essential role

\footnotetext{
${ }^{(1)}$ Forensic Medicine and Clinical Toxicology Department, Al-Azhar University, New Damietta

${ }^{(2)}$ General Internal Medicine, Faculty of Medicine, Mansoura University.
}

in the agricultural world. Irrational and wrong use of pesticide has considerably increased with increased consumer demand. Widespread use of pesticides in agriculture causes environmental pollution and severe health risks such as acute and chronic human poisoning (Abdollahi et al., 2014; Stokes et al., 2015).

In addition to spraying, other way of exposure to pesticides including formulation and handling without consideration of safety 
tips also contribute to the emergence of toxic side effects (Bhatnagar et al., 2012).

There is evidence, indicating that environmental contact, with pesticides is considered a risk factor for thyroid diseases. It has been reported that special insecticides, herbicides and fungicides are endocrine disruptors. Their functions performed by different mechanisms such as inhibition of iodine absorption, intervention in thyroid hormone receptor, binding to transfer proteins, intervention with iodothyronine deiodinases, increased thyroid hormones clearance and intervention in expression of thyroid hormone (Rakitsky et al., 2010; Zoeller, 2007).

Both lindane and chlordane are among organochlorine insecticides, which have been reported to affect the level of thyroid hormones in humans (Langer et al., 2016).

Increase in chlordane level of breast milk is related to congenital hypothyroidism (Nagayama et al., 2014).

Studies on the manufacturers of organochlorine pesticides, especially lindane and organophosphorus insecticides, have demonstrated increase of thyroid stimulating hormones (TSH) and decrease of T3 in these workers compared with the control ones (Zaidi et al., 2014).

Malathion, and organochlorine insecticides affect level of thyroid hormone in catfish and tadpoles of fresh waters (Fordham et al., 2011).

Fungicides have a strong relationship with the probability of thyroid diseases so that causes hypothyroidism in rabbits (Mallem et al., 2006).

In another study on the workers who were in severe contact with ethylene bis dithiocarbamate without any protection, TSH level increased but T4 level did not show any significant difference from that of the control people (Steenland et al., 2007).

The aim of the present work was to study the possible correlation between chronic exposure to some pesticides used at least within the past 12 months as (organophosphorous insecticide) phosphoro di thionate (PDT=Malathion) and (organochlorine insecticide) dichloro-diphenyl trichloroethane (DDT) and disturbance in both thyroid hormones levels and some biochemical markers.

\section{Patients and Methods}

\section{Study population}

A case-control study was conducted from the $1^{\text {st }}$ of December 2016 to $1^{\text {st }}$ of July 2017. After signing informed valid consent to participate in this study, one hundred cases were recruited from department of general internal medicine of Al-Azhar and Mansoura University Hospitals. In addition to 50 subjects as a control group who recruited from medical students.

Cases and controls were eligible if they were above the age of 20 , had a residence in delta area and dealing with pesticide for more than one year, were physically and mentally capable of understanding and completing the questionnaire.

Healthy controls were selected with no manifestation of chronic diseases, alcoholism and diabetes (Miller et al., 2016).

The questionnaire contained inquiries about the following topics:

a) Social and demographic factors (sex, age, region of current residence "urban or rural" and residential history).

b) Personal habits (smoker index i.e. number of cigarette smoker per day multiplied by 
a number of smoking years) into (mild up to 200, moderate from 200-400 and severe above 400) and alcohol intake within the last 30 days).

c) Medical history (especially history of diabetes, bilharziasis and oral anti-thyroid therapy (OAT).

d) Family history of thyroid or autoimmune diseases.

e) History of occupational exposure or spraying to (phosphoro di thionate (PDT) and dichloro-diphenyl trichloroethane (DDT) pesticides, for a long time, petroleum products, and other chemicals) within at least the past 12 months.

f) Agricultural activities (working or exposure in agriculture, types of crops grown and wearing protective clothes).

\section{Clinical examination}

It includes vital signs and general manifestation with special attention to; manifestation of hypothyroidism such as; state of (thyroid, eye, face, weight), easy fatigability, bowel habits, irritability and mental faculties.

\section{Pesticide exposure assessment}

\section{Collection of samples:}

Ten milliliters of blood were collected by venipuncture between 6 and $7 \mathrm{am}$, and it was divided into three aliquots:

a) One of which was collected in EDTA containing test tubes. Phosphoro di thionate (PDT) and dichloro-diphenyl trichloroethane (DDT) residues extraction were done by using (HPLC 3625PSI/250bar. Serial No. PF4250-362) (USA) according to method of (Verebey et al., 1998).
Hexane $(6 \mathrm{~mL})$ and acetone $(3 \mathrm{~mL})$ were added and the contents were shaken at room temperature for $30 \mathrm{~min}$ in a mechanical shaker. The extract was centrifuged for $10 \mathrm{~min}$ at $2000 \mathrm{rpm}$ and the clear top layer of hexane was collected in a clean test tube. Clean up of the samples was done by column chromatography. Elute was collected in a $100 \mathrm{~mL}$ beaker and hexane was evaporated to concentrate the samples. The concentrated residues were dissolved in hexane for further analysis (Eriksson et al., 2014).

b) Part of blood collected in tube containing fluoride for fasting blood sugar estimation.

c) The serum was separated from the remaining third blood samples and stored at $-8 \mathrm{C}^{\mathrm{o}}$. Blood urea, creatinine, uric acid, triglyceride (TG), total cholesterol (TC), high density lipoprotein (HDL) and low density lipoprotein (LDL) were measured using kits of Pars Azmoon Company.

The final diagnosis was done based on the following definitions:

a) Ideal level for total cholesterol was defined as $<200 \mathrm{mg} / \mathrm{dl}$. The moderate risk was between 200 and $239 \mathrm{mg} / \mathrm{dl}$ and high risk level was $\geq 240 \mathrm{mg} / \mathrm{dl}$.

b) For LDL cholesterol, ideal level was below $130 \mathrm{mg} / \mathrm{dl}$, the moderate risk was between 130 and $159 \mathrm{mg} / \mathrm{dl}$ and high risk level was determined as $\geq 160$ $\mathrm{mg} / \mathrm{dl}$.

c) Ideal level for triglyceride was $<200$ $\mathrm{mg} / \mathrm{dl}$, the moderate risk was between 200 and $399 \mathrm{mg} / \mathrm{dl}$ and high risk level was considered $\geq 400 \mathrm{mg} / \mathrm{dl}$.

d) HDL level was defined at two levels of $\leq 35 \mathrm{mg} / \mathrm{dl}$ (risk level) and $>35 \mathrm{mg} / \mathrm{dl}$ (desirable level). 
The TSH, T3 and T4 tests were conducted using radioimmunoassay method (Patan Elm Company). TSH quantitative measurement kit was designed based on immune enzymatic reaction on solid phase. T3 and T4 quantitative measurement kit was designed based on the measurement of competitive immune enzymatic reaction on solid phase.

The following cases were considered the criterion for the presence of thyroid disorders.

a- Clinical hyperthyroidism: T4>12.4 $\mu \mathrm{g} / \mathrm{dl}$ or $\mathrm{T} 3>2.8 \mathrm{nmol} / 1$ and $\mathrm{TSH} \leq 0.1 \mathrm{mIU} / 1$.

b- Subclinical hyperthyroidism: TSH $\leq 0.5$ mIU/1 with normal T3 and T4 levels.

c- Clinical hypothyroidism: $\mathrm{T} 4<4.5 \mu \mathrm{g} / \mathrm{dl}$ and $\mathrm{TSH} \geq 10 \mathrm{mIU} / 1$.

d- Subclinical hypothyroidism: TSH of between 5 and $10 \mathrm{mIU} / 1$ and normal T4.

\section{Statistical Analysis}

Statistical methods of the results were carried out according to fisher exact tests.

The collected data were organized, tabulated and statistically analyzed using SPSS software computer package version 16 (SPSS Inc. Chicago, IL). For quantitative data, all the values were expressed as mean \pm standard deviation (SD). For comparison between the two groups, the students (t) test was used. For qualitative data, number and percent distribution were calculated and Chi square test $\left(\chi^{2}\right)$ was used for comparison between two groups. Pearson's correlation coefficient was used to test correlation between variables. $\mathrm{P}<0.05$ was considered statistically significant (Campbel and Machin, 2009).

\section{Results}

\section{Social and demographic data}

Regarding the demographic data of the studied cases, 60 were males $(60.0 \%)$ and 40 were females $(40 \%)$ in study group, while in control group 30 were males $(60 \%)$ and 20 were females $(40.0 \%)$. There was no significant difference in sex distribution between the study and control groups $(\mathrm{p}=0.699)$.

The mean ages of the studied groups were (31.10 $\pm 01 y)$ in study group and $(26.05 \pm 01 y)$ in the control group. There was no significant difference in age distribution between the studied groups $(\mathrm{p}=0.420)$.

Regarding residence distribution in the study group, urban cases were $10(10.0 \%)$ and rural cases were $90(90.0 \%)$, while in the control group, urban cases were $30(60.0 \%)$ and rural cases were $20(40.0 \%)$, which is statistically significant $(\mathrm{p}=0.004)$.

Regarding the smoker index in the study group, the number of non-smokers was 16 cases $(16.0 \%)$. Mild smokers were detected in 24 cases $(24.0 \%)$, moderate smokers were detected in 35 cases $(35.0 \%)$ and heavy smokers were detected in 25 cases $(25.0 \%)$. On the other hand, regarding smoker index in the control group, the number of non-smokers was 5 cases $(10.0 \%)$, mild smokers were found in 7 cases $(14.0 \%)$, moderate smokers were found in 23 cases $(46.0 \%)$ and heavy smokers were found in 15 cases $(30.0 \%)$. There was a significant difference regarding smoker index between the study and control groups $(\mathrm{p}=0.001)$.

The prevalence of alcohol intake was 7 cases $(7.0 \%)$ in the study group and 2 cases $(4.0 \%)$ in the control group. There was no significant difference regarding alcohol consumption in the studied groups $(\mathrm{p}=0.420)$. 
In the study group, past history of bilharziasis was 70 cases $(70.0 \%)$, that of oral anti-thyroid therapy (OAT) was 95 cases $(95.0 \%)$, that of blood transfusion was 10 cases $(10.0 \%)$, and that of diabetes was 60 cases $(60.0 \%)$. While in control group, past history of bilharziasis was 20 cases $(40.0 \%)$, that of oral anti thyroid therapy (OAT) was 5 cases $(10.0 \%)$, that of blood transfusions was 3 cases $(6.0 \%)$ and that of diabetes was 10 cases $(20.0 \%)$. There was no significant difference in past history between the study and control groups $(\mathrm{p}>0.05)$.

In the study group, history of thyroid diseases was 70 cases $(70.0 \%)$, while in the control group, it was 10 cases $(20.0 \%)$ which is statistically significant $(\mathrm{p}=0.002)$.

The percentage of cases with a history of autoimmune diseases was $7.0 \%$, while in the control group it was $2.0 \%$, which is statistically insignificant $(\mathrm{p}=0.620)$.

Agricultural activities in the study group were working or helping or exposures in 95 cases $(95.0 \%)$ and crops were grown in 70 cases $(70.0 \%)$, while in the control group, they were working in 5 cases $(10.0 \%)$, helping exposures in 10 cases $(20.0 \%)$ and crops were grown in 15 cases $(30.0 \%)$. There was a significant difference regarding agricultural activities between the study and control groups $(p=0.002)$.

The number of cases wearing protective clothes were $10(10.0 \%)$ in the study group and $2(4.0 \%)$ in the control group, which is statistically insignificant $(\mathrm{p}=0.200)$ (Table 1$)$.

\section{Clinical data}

Regarding the clinical data, there was no significant difference between cases and controls as regards systolic and diastolic blood pressure, respiratory, temperature and heart rates $(\mathrm{p}>0.05)$.
Concerning clinical data, there was no significant difference between cases and control groups as regards weight gain, constipation, irritability and decreased mental faculties $(p>0.05)$. Meanwhile there was significant difference between the studied groups as regards thyroid swollen, puffy eye, swollen face and easy fatigability $(p<0.05)$. (Table 2).

\section{Comparisons between chemical investigations finding in the studied groups}

Regarding investigations finding, there is no significant difference between cases and control groups as regards; fasting blood sugar, blood urea, serum uric acid and serum triglyceride $(\mathrm{p}>0.05)$.

Regarding investigations finding, there was a significant difference between cases and control groups as regards serum creatinine, serum cholesterol, high density lipoprotein, low density lipoprotein and thyroid hormones (T3, $\mathrm{T} 4$ \& TSH) $(\mathrm{p}<0.05)$.

Regarding residue finding of phosphoro di thionate (Malathion) and dichloro-diphenyl trichloroethane (DDT), there was a significant difference between cases and controls groups $(\mathrm{p}<0.05)$ (Table 3).

Percent of pesticide exposure assessment in the study cases

Regarding pesticide exposure finding in the study group; phosphoro di thionate (Malathion) was positive in 46 cases $(46.0 \%)$ and dichloro-diphenyl trichloroethane (DDT) was positive in 55 cases $(55.0 \%)$, while in the control group, phosphoro di thionate (Malathion) was positive in 4 cases $(8.0 \%)$ and dichloro-diphenyl trichloroethane (DDT) was positive in 10 cases $(20.0 \%)$. There was an extremely significant difference between the studied groups $(\mathrm{p}<0.005)$ (Table 4$)$. 
Correlation between pesticide exposures and disturbance in thyroid hormones levels and biochemical markers

There was negative correlations of pesticide exposures with fasting blood sugar, blood urea level, high density lipoprotein and thyroid hormones (T3 and T4), and it was nonsignificant $(\mathrm{p}>0.05)$.
There was positive correlations of pesticide exposures with serum creatinine, serum uric acid, serum triglyceride, serum cholesterol and low density lipoprotein, and it was also non-significant ( $\mathrm{p}>0.05)$.

Significant positive correlation was present between pesticide exposure and TSH level $(\mathrm{p}<0.005)($ Table 5).

Table (1): Comparison between the study and control groups as regards demographic and social data by Chi square $\left(\chi^{2}\right)$ test.

\begin{tabular}{|c|c|c|c|c|}
\hline \multicolumn{2}{|c|}{ Studied Parameters } & $\begin{array}{c}\text { Study group } \\
(\mathrm{n}=100)\end{array}$ & $\begin{array}{c}\text { Control group } \\
(\mathrm{n}=\mathbf{5 0})\end{array}$ & p value \\
\hline \multirow{2}{*}{$\begin{array}{l}\text { Sex } \\
\text { n. }(\%)\end{array}$} & Male & $60(60.0 \%)$ & $30(60.0 \%)$ & \multirow{2}{*}{0.699} \\
\hline & Female & $40(40 \%)$ & $20(40 \%)$ & \\
\hline \multicolumn{2}{|c|}{ Age $($ mean \pm SD) in years } & $31.10 \pm 01$ & $26.05 \pm 01$ & 0.420 \\
\hline \multirow{2}{*}{$\begin{array}{l}\text { Region of current } \\
\text { residence } \\
\text { n. }(\%) \\
\end{array}$} & Urban & $10(10.0 \%)$ & $30(60.0 \%)$ & \multirow[b]{2}{*}{$0.004 *$} \\
\hline & Rural & $90(90.0 \%)$ & $20(40 \%)$ & \\
\hline \multirow{4}{*}{$\begin{array}{l}\text { Smoker index } \\
\text { n. }(\%)\end{array}$} & Non & $16(16.0 \%)$ & $5(10.0 \%)$ & \multirow{4}{*}{$0.001^{*}$} \\
\hline & Mild & $24(24.0 \%)$ & $7(14.0 \%)$ & \\
\hline & Moderate & $35(35.0 \%)$ & $23(46.0 \%)$ & \\
\hline & Severe & $25(25.0 \%)$ & $15(30.0 \%)$ & \\
\hline \multicolumn{2}{|l|}{$\begin{array}{l}\text { Alcohol intake } \\
\text { n. }(\%) \\
\end{array}$} & $7(7.0 \%)$ & $2(4.0 \%)$ & 0.420 \\
\hline \multirow{4}{*}{$\begin{array}{l}\text { Past history } \\
\text { n. (\%) }\end{array}$} & Bilharziasis & $70(70.0 \%)$ & $20(40.0 \%)$ & \multirow{4}{*}{$>0.05$} \\
\hline & OAT & $95(50.0 \%)$ & $5(10.0 \%)$ & \\
\hline & $\begin{array}{l}\text { Blood } \\
\text { transfusions }\end{array}$ & $10(10.0 \%)$ & $3(6.0 \%)$ & \\
\hline & \begin{tabular}{|l|} 
Diabetes \\
\end{tabular} & $60(60.0 \%)$ & $10(20.0 \%)$ & \\
\hline \multicolumn{2}{|c|}{$\begin{array}{l}\text { History of thyroid diseases } \\
\text { n. (\%) }\end{array}$} & $90(40.0 \%)$ & $10(20.0 \%)$ & $0.002 *$ \\
\hline \multicolumn{2}{|c|}{$\begin{array}{l}\text { History of autoimmune diseases } \\
\text { n. (\%) }\end{array}$} & $7(7.0 \%)$ & $1(2.0 \%)$ & 0.620 \\
\hline \multirow{3}{*}{$\begin{array}{l}\text { Agricultural activities } \\
\text { n. }(\%)\end{array}$} & $\begin{array}{l}\text { Working or } \\
\text { helping }\end{array}$ & $95(95.0 \%)$ & $5(10.0 \%)$ & \multirow{3}{*}{$0.002 *$} \\
\hline & Exposures & $95(90.0 \%)$ & $10(20.0 \%)$ & \\
\hline & Crops grown & $70(70.0 \%)$ & $15(30.0 \%)$ & \\
\hline \multicolumn{2}{|c|}{$\begin{array}{l}\text { Wearing protective clothes } \\
\text { n. }(\%)\end{array}$} & $10(10.0 \%)$ & $2(4.0 \%)$ & 0.200 \\
\hline
\end{tabular}

n: number, *: Significant. 
Table (2): Clinical manifestations of the studied groups by Student's ( $\mathrm{t}$ ) test.

\begin{tabular}{|c|c|c|c|c|}
\hline \multicolumn{2}{|r|}{ Studied Parameters } & $\begin{array}{l}\text { Study group } \\
(\mathbf{n}=\mathbf{1 0 0})\end{array}$ & $\begin{array}{c}\text { Control group } \\
(\mathbf{n}=\mathbf{5 0})\end{array}$ & p value \\
\hline \multirow{5}{*}{ Vital sign } & $\begin{array}{l}\text { Systolic blood pressure } \\
(\text { mean } \pm \text { SD) }\end{array}$ & $140.80 \pm 10.77$ & $120.56 \pm 6.53$ & 0.077 \\
\hline & $\begin{array}{l}\text { Diastolic blood pressure } \\
(\text { mean } \pm \text { SD })\end{array}$ & $90.77 \pm 7.16$ & $81.25 \pm 6.05$ & 0.218 \\
\hline & Temperature ${ }^{\circ} \mathrm{C}$ & $36.12 \pm 1.06$ & $37.53 \pm 1.61$ & 0.113 \\
\hline & Respiratory rate/min & $17.32 \pm 1.06$ & $18.33 \pm 1.61$ & 0.313 \\
\hline & Heart rate beats/min & $50.97 \pm 5.70$ & $60.33 \pm 6.04$ & 0.112 \\
\hline \multicolumn{2}{|c|}{ Thyroid swollen n. (\%) } & $75(75.0 \%)$ & $1(2.0 \%)$ & $0.042 *$ \\
\hline \multicolumn{2}{|c|}{ Puffy eye n. (\%) } & $85(95.0 \%)$ & $5(10.0 \%)$ & $0.022 *$ \\
\hline \multicolumn{2}{|c|}{ Swollen face n. (\%) } & $85(95.0 \%)$ & $5(10.0 \%)$ & $0.011 *$ \\
\hline \multicolumn{2}{|c|}{ Weight gain n. (\%) } & $60(60.0 \%)$ & $10(20.0 \%)$ & 0.92 \\
\hline \multicolumn{2}{|c|}{ Easy fatigability n. (\%) } & $90(90.0 \%)$ & $19(38.0 \%)$ & 0.012 \\
\hline \multicolumn{2}{|c|}{ Bowel habits (constipation) n. (\%) } & $50(50.0 \%)$ & $3(6.0 \%)$ & 0.92 \\
\hline \multicolumn{2}{|c|}{ Irritability n. (\%) } & $5(5.0 \%)$ & $5(10.0 \%)$ & 0.82 \\
\hline \multicolumn{2}{|c|}{ Decreased mental faculties n. (\%) } & $50(50.0 \%)$ & $1(2.0 \%)$ & 0.92 \\
\hline
\end{tabular}

n: number, * Significant.

Table (3): Comparisons between chemical investigations' findings in the studied groups by Student's (t) test.

\begin{tabular}{|c|c|c|c|c|c|c|}
\hline \multicolumn{2}{|c|}{$\begin{array}{ll}\text { Tests } & \text { Groups } \\
\end{array}$} & \multicolumn{2}{|c|}{ Study group $(n=100)$} & \multicolumn{2}{|c|}{ Control group $(n=50)$} & \multirow[t]{2}{*}{ p value } \\
\hline & & $\mathbf{M}$ & \pm SD & $\mathbf{M}$ & \pm SD & \\
\hline \multicolumn{2}{|c|}{ Fasting blood sugar (mg/dL) } & 80.22 & 10.21 & 73.77 & 6.36 & 0.801 \\
\hline \multicolumn{2}{|c|}{ Blood urea (mg/dL) } & 34.31 & 6.37 & 32.54 & 7.26 & 0.504 \\
\hline \multicolumn{2}{|c|}{ Serum creatinine (mg/dL) } & 1.16 & 0.31 & 1.03 & 0.10 & $0.042^{*}$ \\
\hline \multicolumn{2}{|c|}{ Serum uric acid (mg/dL) } & 4.10 & 1.07 & 4.01 & 1.82 & 0.060 \\
\hline \multicolumn{2}{|c|}{ Serum triglyceride (mg/dL) } & 168.77 & 70.03 & 140.10 & 55.89 & 0.800 \\
\hline \multicolumn{2}{|c|}{ Serum cholesterol $(\mathrm{mg} / \mathrm{dL})$} & 180.19 & 58.58 & 160.11 & 35.07 & $0.047 *$ \\
\hline \multicolumn{2}{|c|}{ High density lipoprotein (mg/dL) } & 34.06 & 9.11 & 39.77 & 10.07 & $0.043^{*}$ \\
\hline \multicolumn{2}{|c|}{ Low density lipoprotein (mg/dL) } & 100.07 & 39.27 & 96.12 & 21.16 & $0.033^{*}$ \\
\hline \multirow{3}{*}{$\begin{array}{l}\text { Thyroid } \\
\text { hormones }\end{array}$} & T3 (nmol/l) & 1.12 & 0.42 & 1.45 & 0.77 & $0.018^{*}$ \\
\hline & $\mathrm{T} 4(\mu \mathrm{g} / \mathrm{dl})$ & 1.94 & 2.51 & 2.33 & 0.63 & $0.007^{*}$ \\
\hline & TSH (mIU/l) & 12.64 & 2.51 & 7.33 & 0.83 & $0.009 *$ \\
\hline \multicolumn{2}{|c|}{$\begin{array}{l}\text { Phosphoro di thionate (Malathion) } \\
\mu \mathrm{g} / \mathrm{L}\end{array}$} & 51.6 & 78.7 & 20.11 & 16.12 & 0.112 \\
\hline \multicolumn{2}{|c|}{$\begin{array}{l}\text { Dichloro-Diphenyl } \\
\text { (DDT) } \mu \mathrm{g} / \mathrm{L}\end{array}$} & 25.16 & 44.61 & 11.44 & 9.22 & $0.011^{*}$ \\
\hline
\end{tabular}

$\mathrm{n}$ : number, * Significant, M: mean, SD: Standard Deviation 
Table (4): Percent of pesticide exposure assessment in the study cases by Chi square $\left(\chi^{2}\right)$ test

\begin{tabular}{|l|c|c|l|}
\hline & $\begin{array}{c}\text { Study group } \\
(\mathbf{n = 1 0 0 )}\end{array}$ & $\begin{array}{c}\text { Control group } \\
(\mathbf{n}=\mathbf{5 0})\end{array}$ & \multicolumn{1}{|c|}{$\boldsymbol{p}$ value } \\
\hline Phosphoro di thionate (Malathion) n. (\%) & $46(46.0 \%)$ & $4(8.0 \%)$ & $0.004^{*}$ \\
\hline Dichloro-Diphenyl Trichloroethane (DDT) n. (\%) & $55(55.0 \%)$ & $10(20.0 \%)$ & $0.002^{*}$ \\
\hline
\end{tabular}

n: number *Significant.

Table (5): Correlation between pesticide exposures and disturbance in thyroid hormones levels and biochemical markers by Pearson's correlation coefficient tests.

\begin{tabular}{|c|c|c|c|c|c|}
\hline \multirow{3}{*}{\multicolumn{2}{|c|}{ Parameters }} & \multicolumn{4}{|c|}{ Pesticide exposures } \\
\hline & & \multicolumn{2}{|c|}{ Study group } & \multicolumn{2}{|c|}{ Control group } \\
\hline & & $\mathrm{r}$ & $\mathrm{p}$ & $\mathrm{r}$ & $p$ \\
\hline \multicolumn{2}{|l|}{ Fasting blood sugar } & -0.32 & 0.08 & -0.1 & 0.57 \\
\hline \multicolumn{2}{|l|}{ Blood urea } & -0.18 & 0.32 & -0.06 & 0.71 \\
\hline \multicolumn{2}{|l|}{ Serum creatinine } & 0.17 & 0.35 & -0.03 & 0.86 \\
\hline \multicolumn{2}{|l|}{ Serum uric acid } & 0.11 & 0.55 & -0.68 & 0.72 \\
\hline \multicolumn{2}{|l|}{ Serum triglyceride } & 0.32 & 0.04 & $0.06-$ & 0.71 \\
\hline \multicolumn{2}{|l|}{ Serum cholesterol } & 0.77 & 0.001 & 0.6 & 0.041 \\
\hline \multicolumn{2}{|c|}{ High density lipoprotein } & -0.18 & 0.001 & -0.03 & 0.73 \\
\hline \multicolumn{2}{|c|}{ Low density lipoprotein } & 0.67 & 0.55 & -0.66 & 0.86 \\
\hline \multirow{3}{*}{ Thyroid hormones } & T3 & 0.02 & 0.02 & 0.72 & 0.73 \\
\hline & T4 & 0.02 & 0.003 & -0.68 & 0.86 \\
\hline & TSH & 0.12 & 0.001 & $0.06-$ & 0.03 \\
\hline
\end{tabular}

r: positive correlation. $\mathrm{r}-$ : negative correlation.

\section{Discussion}

Pesticides are chemical or biological substances used to kill or repel targeted organisms. All pesticides are poisons. In many cases, they are designed to impact the immune, reproductive, or nervous system of insects (Abby and Sarah, 2012).

Pesticides are mainly utilized in agriculture. Pesticides are also applied in homes and gardens. More than 140.000 tones of pesticides are used annually in the European Union for agricultural purposes only (Ramazzini, 2012).

Pesticides are widely used all over the world to increase agricultural yield for crop protection, often replacing the natural processes on which agricultural production had previously depended. Therefore, every person may be exposing to these compounds to some extent; however, farming workers are the group with the maximum exposure. Although acute effects of exposure to pesticides have been specified, their role in chronic diseases has not been well established (Kalender et al., 2015).

Despite using protective equipment in pesticides involved industries, it is possible that people are exposed to particles, liquid or powder of these pesticides at their workplaces. Most of the studies focused on the effect of pesticides on acetyl cholinesterase and many papers have referred to the inhibition of this enzyme by pesticides. Some documents have demonstrated that exposure to the environment with pesticides 
is a risk factor for thyroid diseases (Toft et al., 2006; Langer et al., 2016).

So, the objective of this work was to study the possible correlation between some pesticides exposure, used at least within the past 12 months, such as phosphoro di thionate (PDT $=$ Malathion, an organophosphorus insecticide) and dichloro-diphenyl trichloroethane (DDT, an organochlorine insecticide), and disturbance in both thyroid hormones levels and some biochemical markers. The study was conducted from the $1^{\text {st }}$ of December 2016 to $1^{\text {st }}$ of July 2017 in Al-Azhar University Hospital (New Damietta).

Regarding the demographic data of the studied cases, 60 were males $(60.0 \%)$ and 40 were females (40\%) in study group,

Sex incidence; males were $(60 \%)$ and $(40 \%)$ were females in study group. The majority of male cases were due to the fact that male are more likely to report the use of pesticide in agriculture accepted in the society (Mucci et al., 2001). Male dominance in pesticides was also recorded by (Milena et al., 2015).

Regarding the mean age in years it was $(31.10 \pm 01 y)$ in the study group and (26.05 $\pm 01 y)$ in control group. These finding signify an alarming trend in the prevalence of pesticides exposure in such age. These results are in agreement with (Langer et al., 2013), in a case-control study in Greece, in which pesticides exposure at mean age $(41 \pm 10 \mathrm{y})$ are significantly associated with an increased risk of endocrine disruptors (Milena et al., 2015).

Regarding residence distribution in the study group, urban was $(10.0 \%)$ and $(90.0 \%)$ was rural. These results were in agreement with (Lacasana et al., 2010). as reported that the farming workers are the group with the maximum exposure to pesticide. Although acute effects of exposure to pesticides have been specified, their role in chronic diseases has not been well established.

Regarding the smoker index in the study group; the number of non-smokers was $(16.0 \%)$, mild smokers was $(24.0 \%)$, moderate was $(35.0 \%)$ and heavy was $(25.0 \%)$, while smoker index in the control group, number of non smokers was $(10.0 \%)$, mild smokers was $(14.0 \%)$, moderate was $(46.0 \%)$ and heavy was $(30.0 \%)$. This observation was recorded (Andersson, 2009).

The prevalence of alcohol intake, was $(7.0 \%)$ in study group and was $(4.0 \%)$ in the control group. These results are not agreement with (EL-Serag, 2007). These explained by deceased number of alcohol consumption due to religious practices, $(7.0 \%)$ of cases and $(4 \%)$ in control.

In the study group, past history of thyroid diseases, autoimmune diseases and bilharziasis were $(70.0 \%)$, (OAT) was $(95.0 \%)$, blood transfusion was $(10.0 \%)$ respectively and diabetes was $(60.0 \%)$. The result of diabetes was in agreement with (Patricia, 2010), as reported that diabetic patients have a higher prevalence of thyroid disorders compared with the normal population.

Agricultural activities in the study group, is working or helping or exposures was $(95.0 \%)$ and crops grown was $(70.0 \%)$ while in control group working or helping was $(10.0 \%)$, exposures was $(20.0 \%)$ and crops was $(30.0 \%)$. The number of cases wearing a protective clothes in the study group was (10.0\%) and was $(4.0 \%)$ in the control group. These are in accordance with (Xu et al., 2013). It is reported that farmers and spraying people are close in touch with pesticides in different ways, which are susceptible to endocrine dysfunction. Despite using protective equipment in pesticides involved industries, it is possible that people are exposed to particles, liquid or powder of these pesticides at their workplaces. Most of the studies focused on the effect of pesticides on 
acetyl cholinesterase and many papers have referred to the inhibition of this enzyme by pesticides. Some documents have demonstrated that exposure to the environment with pesticides is a risk factor for thyroid diseases (Toft et al., 2006; Langer et al., 2016).

Regarding the clinical data, there is no significant difference between cases and controls as regard systolic and diastolic blood pressure, respiratory, temperature and heart rates.

Regarding clinical data, there is no significant difference between cases and control groups as regard weight gain, constipation, irritability and decreased mental faculties. These results are not in agreement with (Gerra et al., 2013), who reported significant differences between studied patients as regard clinical data as most of the cases are diagnosed early in a clinical or subclinical state.

There is significant difference between studied groups as regard (thyroid swelling, puffy eye, swollen face and easy fatigability). Hollowell, et al. (2002) found that the prevalence of self-reported clinical thyroid manifestations of pesticide applicators is $12.5 \%$, higher than in the general population.

As regarding Investigation finding, there is no significant difference between cases and controls groups as regard; fasting blood sugar, blood urea, serum uric acid and serum triglyceride. While there is a significant difference between cases and controls groups as regard; serum creatinine, serum cholesterol, high-density lipoprotein, low density lipoprotein and thyroid hormones (T3, T4 and TSH). There is slightly above the critical level $(p=0.052)$ as regarding serum uric acid, between the study and control groups. These results are in agreements with Toft et al. (2006) and Langer et al. (2016) who reported that this is attributed to inhibition of acetyl cholinesterase by pesticides.

In the present study TSH level was more than $10 \mathrm{mIU} / 1$, which indicative of hypothyroidism. Considering different studies, it can be stated that stimulation of TSH through negative feedback can be affected by exposure to pesticides (Langer et al., 2003).

Regarding pesticide exposure finding in the study group; phosphoro di thionate (Malathion) is positive in (46.0\%) and (DDT) is positive in $(55.0 \%)$, while in control group phosphoro di thionate (Malathion) is positive in 4 cases $(8.0 \%)$ and (DDT) is positive in 10 cases $(20.0 \%)$. These results are in agreements with Toft et al. (2006) and Langer et al. (2016) who showed that in animal studies, the exposure to pesticides such as (DDT), amitrol and thiocarbamate related compounds resulted in decreased free and total T3 and T4 along with the increased of TSH level. Vettorazzi et al. (2014) and Jeong et al. (2016) also reported that both lindane and chlordane are organochlorine insecticides, which have been reported to affect the level of thyroid hormones in humans.

Significant positive correlation between pesticide exposures and TSH level was found. These results are not in agreement with Toft et al. (2006) and Langer et al. (2016) who reported significant stimulation of TSH through negative feedback induced by exposure to pesticides.

\section{Conclusion}

1. The results of the present study revealed a relation between working or exposures to Phosphoro di thionate (Malathion) as it is positive in (46.0\%) and (DDT) as it is positive in $(55.0 \%)$ and occurrence of hypothyroidism, especially among agriculture working in rural area. 
2. TSH measurement is the first useful test for evaluating hypothyroidism. Other measurements such as T3 and T4 would complement diagnosing of thyroid disorders.

Due to limited literature on the endocrinal disturbance of pesticides compounds, it is recommended that:

1. Any patient with suspect manifestation of hypothyroidism must be screened for pesticides especially in rural area dealing with them.

2. People who are in touch with pesticides, especially those who spray farmlands and gardens, must use a sufficient protective instruments or do consider safety guidelines even through social media.

3. More researches are needed for future testing other pesticide compounds and other endocrinal systems.

4. Further studies should be undertaken to assess specific risk factors that suppress thyroid activity in more detail; such certain diet habits such as flax seed oil, soy oil, sunflower oil, and vegetable oils as it might be involved in the etiology of hypothyroidism to avoid it.

\section{References}

Abby, S. and Sarah, J. (2012): "The health effects of pesticides used for mosquito control principal". Environ. Health Perspect., 105 (10): 26-30.

Abdollahi, M.; Jalali, N.; Sabzevari, O.; et al. (2014): "A retrospective study of poisoning in Tehran". J. Toxicol. Clin. Toxicol., 35(4): 387-393.
Andersson, K. (2009): "Effects of cigarette smoking on learning and retention". Psychopharmacologia (Berlin), 41: 1-5.

Bhatnagar, V.K.; Sharma, R.P. and Malviya, A.N. (2012): "Effects of pesticidal stress amongst pesticide factory workers in Agra India". Public Health, 94(6): 375-378.

Campbel, M.J., and Machin, D. (2009): Statistical inference. In: Medical Statistical. A Common Sense Approach, Campbel, M. J. and Machin, D. (Ed). John Wiley and Sons Chichester, New York, Brisbance, Toronto, Singapor, P.P. 69.

EL-Serag, H.B.; Hampel, H. and Javadi, F. (2007): "The association between hormonal disorder and hepatocellular carcinoma: a systematic review of epidemiologic evidence". Clin. Gastroenterol. Hepatol., 4: 369-380.

Eriksson, M.; Hardellm, L.; Berg, N.; et al. (2014): "Soft tissue sarcomas and exposure to chemical substances. A case referent study". Br. J. Ind. Med., 38: 2733.

Fordham, C.L.; Tessari, J.D.; Ramsdell, H.S. and Keefe, T.J. (2011): "Effects of malathion on survival, growth, development, and equilibrium posture of bullfrog tadpoles (Rana catesbeiana)". Environ. Toxicol. Chem., 20 (1): 179-184.

Gerra, G.; Cersini, S.; Zaimovic, A.; et al. (2013): "Neurendocrine and behavioral response to opioid receptor-antagonist during heroin detoxification relationship with personality traits". Int. Clin. Psychopharmacological., 18: 261-268.

Gilden, R.C.; Huffling, K. and Sattler, B. (2010): "Pesticides and health risks". J. Obstet. Gynecol. Neonatal. Nurs., 39: 103110. 
Hollowell, J.G.; Staehling, N.W. and Flanders, W.D. et al. (2002): "Serum TSH, T(4), and thyroid antibodies in the United States population. National health and nutrition examination survey". J. Clin. Endocrinol. Metab., 87(2): 489-499.

Jeong, S.H.; Kim, B.Y.; Kang, H.G.; et al. (2016): "Effect of chlorpyrifos-methyl on steroid and thyroid hormones in rat F0- and F1-generations". Toxicology, 220(2-3): 189-202.

Kalender, S.; Ogutcu, A.; Uzunhisarcikli, M.; et al. (2015): "Diazinon-induced hepatotoxicity and protective effect of vitamin $\mathrm{E}$ on some biochemical indices and ultra-structural changes". Toxicology, 21 (3): 197-206.

Lacasana, M.; Lopez, I.; Rodriguez, M.; et al. (2010): "Association between organophosphate pesticides exposure and thyroid hormones in floriculture workers". Toxicol. Appl. Pharmacol., 243(1): 19-26.

Langer, P.; Kocan, A.; Tajtakova, M.; et al. (2003): "Possible effects of polychlorinated biphenyls and organochlorinated pesticides on the thyroid after long-term exposure to heavy environmental pollution". J. Occup. Environ. Med., 45(5): 526-532.

Langer, P.; Tajtakova, M.; Fodor, G.; et al., (2013): "Increased thyroid volume and prevalence of thyroid disorders in an area heavily polluted by polychlorinated biphenyls". Eur. J. Endocrinol., 139 (4): 402-409.

Langer, P.; Tajtakova, M.; Kocan, A.; et al. (2016): "Multiple organochlorine pollution and the thyroid". Endocr. Regul., 40(2): 46-52.
Mallem, L.; Boulakoud, M.S. and Franck, M. (2006): "Hypothyroidism after medium exposure to the fungicide maneb in the rabbit Cuniculus lepus". Commun. Agric. Appl. Biol. Sci., 71(2): 91-99.

Milena, K.; Ivan, B.; Dragan, D.; et al. (2015): "Case-control study, hepatocellular carcinoma, risk factors". Institute of Infectious and Tropical Diseases, Clinical Center of Serbia, Belgrade, GIT, 29: 519532.

Miller, M.D.; Crofton, K.M.; Rice, D.C. and Zoeller, R.T. (2016): "Thyroid-disrupting chemicals: interpreting upstream biomarkers of adverse outcomes". Environ. Health Perspect., 117: 10331041.

Mucci, L.A.; Kuper, H.E.; Tamimi, R.; et al. (2001): "Age at menarche and age at menopause in relation to hepatocellular carcinoma in women". Br. J. Obstet. Gynecol., 108: 291-294.

Nagayama, J.; Kohno, H.; Kunisue, T.; et al. (2014): "Concentrations of organochlorine pollutants in mothers who gave birth to neonates with congenital hypothyroidism". Chemosphere, 68(5): 972-976.

Patricia, W.U. (2010): "Thyroid Disease and Diabetes". Clinical Diabetes, 22(1): 17571761.

Rakitsky, V.N.; Koblyakov, V.A. and Turusov, V.S. (2010): "Nongenotoxic (epigenetic) carcinogens: pesticides as an example. A critical review". Teratog. Carcinog Mutagen., 20(4): 229-240.

Ramazzini, C. (2012): "Statement on the control of pesticides in the European Union: A call for action to protect human health". Am. J. Ind. Med., 52: 176-177.

Steenland, K.; Cedillo, L.; Tucker, J.; et al. (2007): "Thyroid hormones and cytogenetic outcomes in backpack 
sprayers using ethylenebis (dithiocarbamate) (EBDC) fungicides in Mexico". Environ. Health Perspect., 105 (10): 1126-1130.

Stokes, L.; Stark, A. Marshall, E. and Narang, A. (2015): "Neurotoxicity among pesticide applicators exposed to organo-phosphates". Occupational and Environmental Medicine, 52 (10): 648653.

Toft, G.; Flyvbjerg, A. and Bonde, J.P. (2006): "Thyroid function in Danish green house workers". Environ. Health, 5: (1):32.

Verebey, K.; Buchan, B.J. and Turner, C.C. (1998): Laboratory testing. In: Clinical Textbook of Active Disorder. Frances, R.J., Miller, S.I. (Eds), 2nd ed. Guiliford Press. New York, London, P.P. 77-88.
Vettorazzi, G.; Almeida, W.F.; Burin, G.J.; et al. (2014): "International safety assessment of pesticides: dithiocarbamate pesticides, ETU, and PTU a review and update". Teratog. Carcinog. Mutagen, 15 (6):313-337.

Xu, Z.; Li, X.; Su, Q.; et al. (2013): "Effect of synthetic pyrethroid pesticide exposure during pregnancy on the growth and development of infants". Asia Pacific Journal of Public Health, 25: 72-79.

Zaidi, S.S.; Bhatnagar, V.K.; Gandhi, S.J. et al. (2014): "Assessment of thyroid function in pesticide formulators". Hum. Exp. Toxicol., 19(9): 497-501.

Zoeller, R.T. (2007): "Environmental chemicals impacting the thyroid: targets and consequences". Thyroid, 17(9):811-817. 


\title{
إمكانية العلاقة بين التعرض المزمن لبعض المبيدات وحدوث اعتلال بمستويات هرمون الغدد الدرقية وبعض الدلالات الكيمائية
}

\author{
مصطفى عبد المنفم محمد' ، خالل محمد طله ' \\ 'قسم الطب الثرعي والسموم الإكلينيكية، كلية الطب جامعة الأزهر لدمياط الجديدة \\ بقسم الباطنة العامة كلية الطب- جامعة المنصورة
}

غالبأ ما تستخدم المبيدات سواءً كانت مبيدات (حشرية، نباتية، للجرذان، للطحالب أو الفطريات) بطريقة عشو ائية وبكميات كبيرة و التي بدور ها تؤدي إلى التلوث البيئي. إن لهذه المبيدات آثار آ سلبية على معظم أجهزة

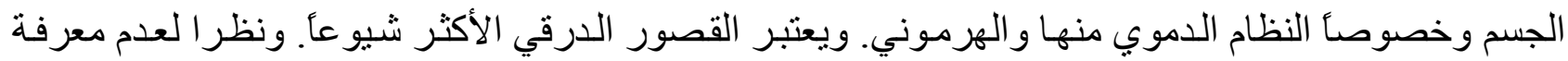

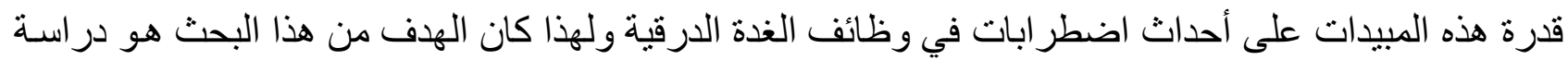
العلاقة بين التعرض المزمن لبعض هذه المبيدات (ثنائي ثيونات الفوسفور ات و المعروف تجارياً باسم الملاثيون)

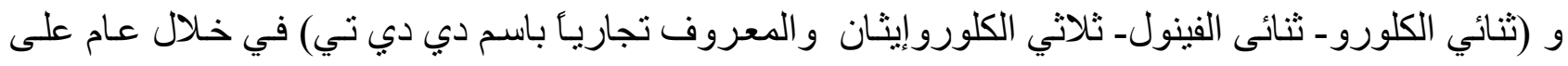
الأقل و إمكانية حدوث اضطر ابات في كلٍ من مستوى هرمون الغدة الدرقية وبعض التغير ات الكيميائية الحيويـة.

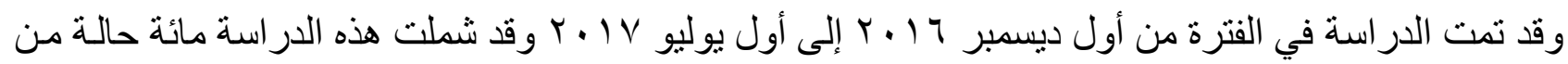

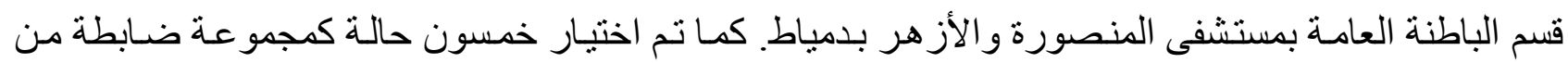

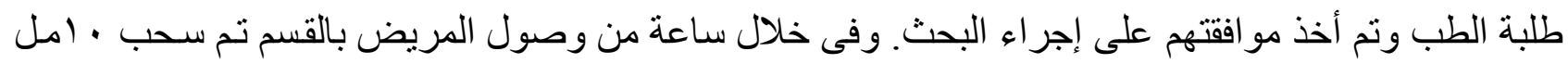

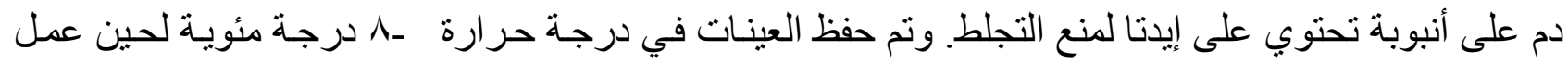
كلِ من التحاليل المعملية للكثف عن هذه المبيدات باستخدام "جهاز الاستشر اب السائلي الرفيع عالي الأداة" في دئي

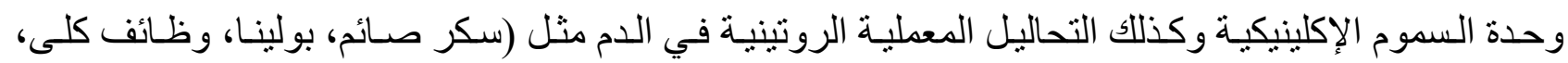

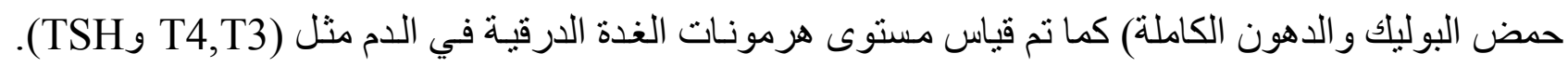

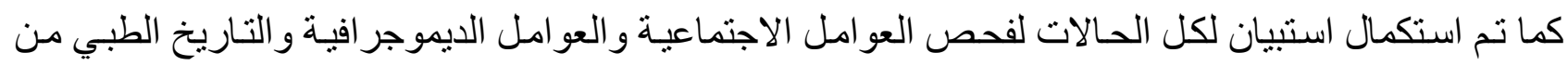

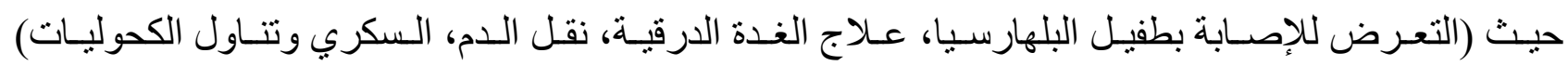

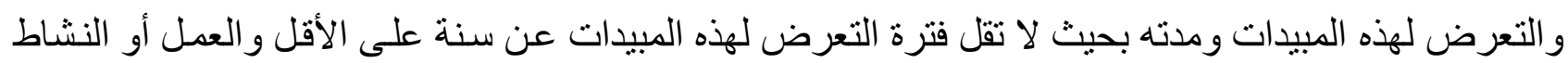

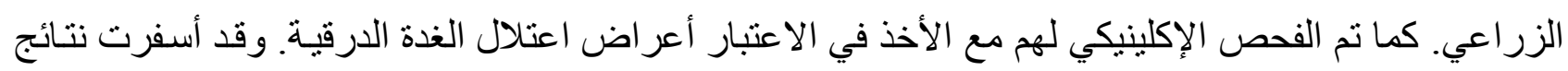

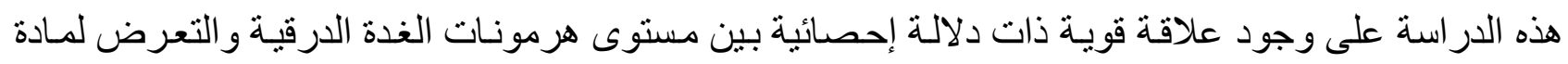

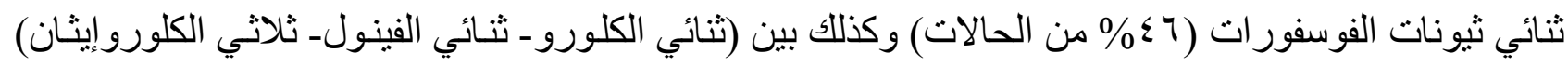

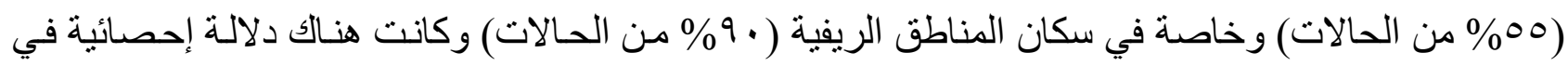

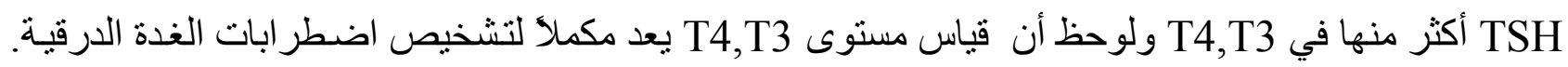
كما وجدت أيضاً علاقة قوية ذات دلالة إحصائية بين التعرض لهذه لمركبات وبين كريـاتينين وكوليسترول الدم 
و الدهون عالية وقليلة الكثافة وهرمونات الغدة الدرقية. كما أظهرت أيضأ وجود ارتباط ذي دلالة إحصائية بين

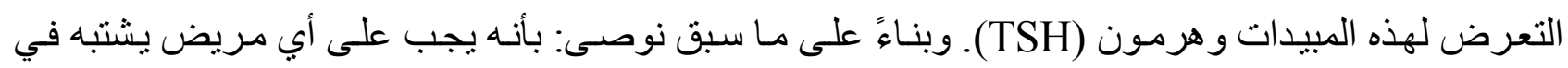

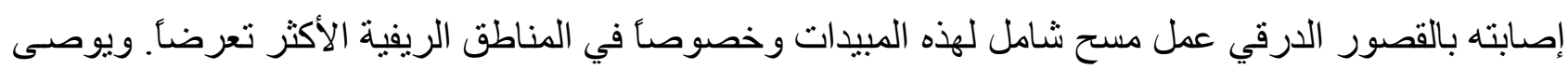

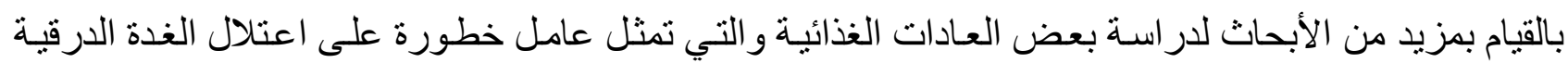
و المحتوية على (الكلورين، البرومين، الفلورين وبروميد الميثيل) لتجنبها ولتفاديها. ويجب على الإنى الثخاص الذين

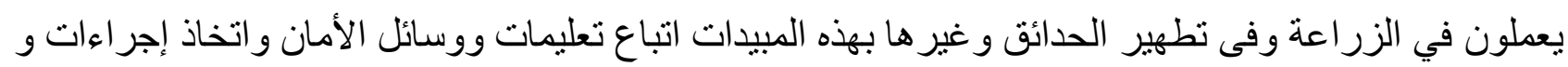

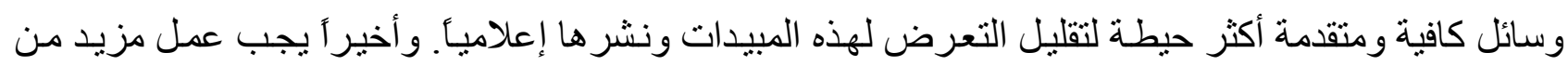

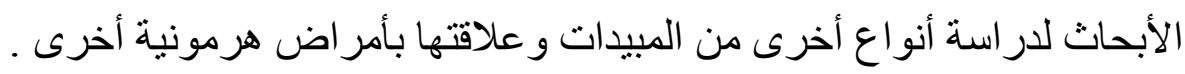

